Covered in: Web of Science (WOS); EBSCO; ERIH+; Google Scholar; Index Copernicus; Ideas RePeC; Econpapers; Socionet; CEEOL; Ulrich ProQuest; Cabell, Journalseek; Scipio; Philpapers; SHERPA/RoMEO repositories; KVK;

WorldCat; CrossRef; CrossCheck

2022, Volume 13, Issue 1, pages: 66-86 | https://doi.org/10.18662/po/13.1/385

\section{Gender and Age Specificity of Determination of Value-motivational Attitudes of Volunteer Movement in Postmodern Society}

\section{Larysa SPITSYNA ${ }^{1}$, Hennadiy KOVAL ${ }^{2}$}

${ }^{1}$ Candidate of Psychological Sciences, Associate Professor of the Department of Psychology Zaporizhzhia National University, Zaporizhzhia, Ukraine, lorasp14@gmail.com

${ }^{2} \mathrm{Ph} . \mathrm{D}$. student of the Department of Psychology Zaporizhzhia National University, Zaporizhzhia, Ukraine, Gennadiy83zp@i.ua

\begin{abstract}
The article is devoted to the analysis of gender and age specifics of determining value-motivational trends of volunteering. The purpose of the research is to reveal the specifics of socio-psychological factors of volunteering, and, above all, the role and place of age and gender of the volunteer. The research was implemented by filling out an individual volunteer questionnaire. The sample of the research consisted of 302 volunteers aged 17 to 80 years from more than 15 cities of Ukraine. In particular, it is shown that depending on what motivational trends dominate in an individual profile of the SVM volunteer, and, therefore, direct his/her individual activity, the resource of readiness that is implemented in rendering aid, is specifically related to them. In addition, it was found that the meaningfulness of activity on giving help can exhaust own high indicators in the relationship to the implementation of various motivational trends. In turn, it is also shown that individual value-motivational trends to be sensitive on age and gender. The identified features of the gender and age of the volunteer are an important component in the system of factors of the socio-psychological conditioning of volunteering activity. This allows it is to link the specifics of their impact with the characteristics of value-motivational trends, the motivational potential of which is realized by volunteers on giving to help.
\end{abstract}

Keywords: age, gender specifics, volunteering, value-motivational trend, motivation.

How to cite: Spitsyna, L., \& Koval, H. (2022). Gender and Age Specificity of Determination of Value-motivational Attitudes of Volunteer Movement in Postmodern Society. Postmodern Openings, 13(1), 66-86. https://doi.org/10.18662/po/13.1/385 


\section{Introduction}

Many researchers, including the authors of this work, consider its unpredictability, multifactoriality and variability to be a feature of the modern world of the last few decades. To define these key characteristics in recent years, they even began to use the special concept of VUCA, which is an acronym for the English words "volatility", "uncertainty", "complexity" and "ambiguity". In essence, this is a socio-psychological model of our postmodern world and the mental response of society to the challenges of our time.

At the same time, the existence of parallels between the worldview of postmodernism and post-classical science with its uncertainty, incompleteness and complexity is obvious (Liotard, 1998). These processes are connected with the reflection of requirements for modern psychological studies within the ideas of post-non-classical rationality (Guseltseva, 2018), where a subject is not only an integral part of the perceiving reality, but at the same time is a creator (constructor) of cognitive capabilities (Spitsyna, 2011). One of the most significant versions of postmodernism in psychology and, in particular, in a post-non-classical discourse of sociality (Tytarenko, 2014), has become the "social constructionism" proposed by K. Gergen (Gergen, 1985).

The central principle of the postmodern worldview is that beliefs, laws, social customs, everything that makes up the psychological fabric of "reality" - gradually arises from social interaction. In other words, people jointly construct their realities by living those (Berger \& Lukmann, 1966, p. 28).

As Clifford Geertz notes while modernist thinkers tend to be interested in facts and rules, postmodernists are interested in meaning. In their search for meaning and its study, postmodernists find more use in metaphors from the humanities than in modernist metaphors borrowed from nineteenth-century physics (Clifford, 1983).

Thus, the post-classical model of scientific knowledge is in fact a modern stage in the development of scientific knowledge, which adds to the principles of non-classical science the requirement to take into account the value-target attitudes of the subject of scientific knowledge. These requirements not only do not contradict the ideals of objectivity of scientific knowledge, but are its condition that explains the inclusion of personal knowledge as a part of the scientific (Polanyi, 1958).

In place of such postulates of classical science as simplicity, stability, determinism, postulates of complexity, probability, instability are put 
forward. As a result of studying various complexly organized systems capable of self-organization (from physics and biology to economics and sociology), a new - nonlinear - thinking, a new "picture of the world" is formed (Haken, 2009). The main characteristics of post-classical methodology are nonequilibrium, instability, irreversibility of events in postmodern society - mark a kind of "postmodern state" in science, and, in particular, in psychology.

A postmodern aspect of the studying phenomenon of volunteering is its specificity. This specificity is that with the help of civil society institutions performs tasks that are traditionally associated with the tasks and functions of the "nation state" as a specifically modernist project. That is, a project that not only underwent its formation and development in the era modern, but is almost its main "creation". Accordingly, the studied phenomenon by the very fact of its existence allows us to talk about the presence of a certain fracture. After all, as a rule, previous social movements (and the theories that explained them) developed in the light of the coverage of the opposition of social movements to the institutions of the state or the norms of traditional society. Instead, it was not about the possibility of their "synergistic" interaction in sustaining the progress of communities, which is observed now. In particular, a renewed public demand for the national and civil security has gained one of its solutions through the activation of volunteering as a specific type of civic engagement and response to the acute social need for self-organization to protect the values of integrity, sovereignty, independence and other hallmarks of statehood.

The relevance of the study of the socio-psychological aspects of the volunteer activities (VA) as a phenomenon of postmodern society, as a whole, and the specificity of its conditioning by the system of sociopsychological factors, in particular, does not raise any doubts today.

Volunteering in the world and the Ukrainian science, in various aspects of its sense, has a sustainable story of a scientific reflexing, where diversified aspects of the topic have been developed. Volunteering in the territory of Ukraine from the start of gaining independence and till now has been manifested in a complex dialectics of scientific study as a subject of research and formation as a phenomenon of postmodern society, which is reflected in scientific developments (Lyuta, 2016; Yurchynska \& Krutsyuk, 2017). A separate branch of the today's domestic volunteering problem area is the analysis of its specificity amid the war conflict (Korniyevskyy \& Horyelov, 2015), where the VA is manifested through the form of a social volunteer movement (SVM), which provides aid to victims and participants in the military conflict. 
Today, undoubtedly, it is possible to talk about maintaining the steady interest of scientists in the development of the volunteering problem area in the specificity of its interconnections with quite a wide range of psychological and socio-psychological phenomena and manifestations. Study of the role and the place of the altruistic reasons, signs of empathy, facilitation, care and moral position of a personality, his/her individual and cultural values concerning their contribution to the specificity of the VA is traditional (Juujärvi et al., 2012; Koval \& Spitsyna, 2021; Oswald, 1996; Wymer, 1997). However, interconnections of the VA with quite specific personality manifestations, such as spontaneity (Simsa et al., 2019), happiness (Lee, 2019), hardiness (Yurchynska \& Krutsyuk, 2017) etc., are subject to analysis and study. At the same time, less attention has been paid to the analysis of the role and the place of the gender and age of a volunteer in the system of socio-psychological factors of the VA.

The purpose of the article is to establish the specificity of sociopsychological factors of the VA, and, first of all, the role of gender and age in the determination of value-motivational attitudes of volunteer. The mentioned results will complement the concept of a set of prognostic variables that make it possible to determine the specificity of the VA depending on the context of its implementation.

\section{Theoretical analysis}

Let us recall, first of all, the definition of the object of social psychology, suggested by M. Slyusarevskyy, - «individual and non-individual (group, collective, mass) psychic phenomena, that are conditioned by the historical and cultural unity of people, their interaction, common activity and are manifested in the peculiarities of an individual, group and intergroup behavion» (Slyusarevskyy, 2013, p. 30). As we can see, the specificity of socio-psychological conditioning of individual and non-individual psychic phenomena (which, in particular, are manifested in the VA) is connected with a certain number of factors - a historical and cultural unity of people, their interaction and common activity. At the same time it is important for our study that the above-mentioned set of specific socio-psychological factors can be considered as an interconnected system, the total influence of which conditions the specificity of socio-psychological conditioning of the VA. The above mentioned understanding of consistency of connection between the socio-psychological factors, in its turn, makes it possible to generalize it in the term "commonality". At the same time, the meaning of this term is described as a characteristic of the connection, formed in the space of socio-psychological interaction, which accentuates (characterizes) : 
on the one hand - the specificity of gaining and functioning of such a connection; on the other hand - the specificity of the "whole", which has been created as a result of the connection.

It is possible to additionally reveal the above-mentioned understanding of the specificity of socio-psychological conditioning in the above-mentioned generalization, having referred to the steady ideas of the structure of activity in the sense, developed in the work by A. Leontyev. In particular, as is known, a range of the following substructures can be singled out within the concept: actions with the conditions, organizing it; operation with the purpose, organizing it; activity as such with the motive, organizing it (Leontyev, 1975). Therefore, it is evident, that socio-psychological aspects of conditioning the VA are associated with the level of activity as such and are designed to reveal the specificity of its motivation. At the same time the specific issue of understanding the motive as a socio-psychological factor involves the necessity of singling out at least two non-identical areas of conditioning. On the one hand, the conditioning of a certain activity should be meant. On the other hand, the object of a direct conditioning must be an interconnection between volunteers of the SVM, i.e. the connection between them, which must be formed and maintained within a period of time sufficient for carrying out a certain activity.

The above-described sense of commonality within the context of the empirical study of the specificity of conditioning the VA by the system of socio-psychological factors concedes the necessity of its parameterization. At the same time, one should take into account both the conditioning by the commonality of the specificity of the inter-individual connection at the level of interaction volunteer $\leftrightarrow$ recipient and volunteer $\leftrightarrow$ volunteer, and the conditioning of commonality by the inter-group connection at the level volunteer $\leftrightarrow$ community. We associate a further progress in singling out the specificity of commonality for coping with the tasks of this study with the operationalization of such constructs as - volunteering activity; values; age and gender characteristics. In particular, direct characteristics of the VA, on the one hand, and gender and age characteristics of a volunteer, on the other hand, make it possible to reconstruct the specificity of their interconnection with motivational factors. We are considered the value-motivational trends of the volunteer as such motivational factors. At the same time, we rely on the developments of S. Schwartz, which showed the possibility of grouping universal individual values into a holistic motivational structure. This structure acquires the shape of a motivational circle with consistent value conflicts and compatibilities (Schwartz, 1992). In addition, the established characteristics of the VA are elaborated by us through the parameters of 
meaningfulness and empathy, where the latter are a resource of readiness to provide aid (Koval \& Spitsyna, 2021; Koval, 2019).

\section{Methods of the study}

\subsection{Research participants}

The study sample was composed of 302 volunteers from more than 15 cities of Ukraine. There were 45 male and 257 female volunteers. Age of respondents - from 17 to 80 years (of them: 17-30 - 40 respondents; 31-40 63 respondents; 41-50 - 72 respondents; 51-60 - 73 respondents; 61-80 - 54 respondents).

\subsection{Research measures}

Empirical data and figures, provided for by the model, were directly collected in 2018-2019. In particular, in order to achieve the purpose and fulfil the tasks of the study, the data, obtained by the results of the following instruments, have been used: «Life-meaning orientations test» (LMO) by D. Leontyev (Leontyev, 2000); «Interpersonal reactivity index» (IRI) by M. Davis (Davis, 1983), adapted by T. Karjagina, N. Kuhtova et all (Karjagina et al., 2013, 2016) - for registration of the scores of the indicators of established socio-psychological characteristics of the VA; "«Portrait Values Questionnaire» by S. Schwartz (Schwartz, 1992), adapted by I. Semkiv (Semkiv, 2010) - for registration of scores of indicators of individual value-motivational trend as general motivational factors of the VA, age and gender distribution of respondents - for registration of scores of indicators of established characteristics of the volunteer's personality.

The processing of mathematical and statistical data was carried out on the basis of MS Excel 2007 and SPSS 17.0 software algorithms. The procedures used: primary descriptive statistics - to identify standard indicators of the variables under study and sample parameters; Student's ttest calculation - to ascertain the veracity of statistical discrepancies between the compared subgroups; calculation of the Spearman rank correlation coefficient $(\varrho)$ and the Pearson connectivity coefficient $(\mathrm{P})$ - to identify the presence of functional relationship between the variables under study. 


\section{Results of the study}

We can see the presence of distinguishing peculiarities from the presented results of the statistical analysis of peculiarities of the gender distribution of volunteers based on the results of the LMO instrument (see Table 1). In particular, deviation from the average towards the side of prevailing of both a general indicator of meaningfulness and indicators on individual scales is statistically significant for female volunteers.

Table 1. Gender-related statistical differences in the distribution of indicators on scales of the LMO instrument

\begin{tabular}{|c|c|c|c|c|c|}
\hline & \multicolumn{2}{|c|}{ Male $(N=45)$} & \multicolumn{2}{|c|}{ Female $(N=257)$} & \multirow[t]{2}{*}{$t_{e}$} \\
\hline & $M$ & $S D$ & M & $S D$ & \\
\hline Purpose & 34,33 & 5,633 & 36,48 & 5,659 & 2,355 \\
\hline Process & 31,76 & 5,601 & 33,82 & 5,365 & 2,296 \\
\hline Result & 27,02 & 4,765 & 27,97 & 4,140 & 1,258 \\
\hline LC Me & 21,78 & 3,884 & 23,41 & 3,786 & 2,614 \\
\hline LC Life & 30,51 & 6,646 & 32,88 & 6,091 & 2,236 \\
\hline ML & 106,44 & 16,471 & 113,59 & 15,60 & 2,706 \\
\hline
\end{tabular}

Notes: ML - meaningfulness of life; LC Me - locus of control Me; LC Life - locus of control Life; $\mathrm{t}_{\mathrm{e}}$ - empirical score of Student's t-test; $\mathrm{t}_{\mathrm{t}}=1,968$ at $\alpha=0.05 ; 2,592$ at $\alpha=0.01 ; \alpha-$ level of statistical significance.

$N=302$;

The result of the comparative statistical analysis for volunteer sample makes it possible to confirm the presence of gender-related differences for indicators on the IRI $-« \mathrm{EC} »$ and $« \mathrm{PT} »$ scales as well (see Table 2).

Table 2. Gender-related statistical differences in the distribution of indicators on scales of the IRI instrument

\begin{tabular}{cccccc}
\hline \multirow{2}{*}{ Scales } & \multicolumn{2}{c}{ Male $\mathbf{( N = 4 5 )}$} & \multicolumn{2}{c}{ Female $\mathbf{( N = 2 5 7 )}$} & \multirow{2}{*}{$\mathbf{t}_{\mathbf{e}}$} \\
\cline { 2 - 5 } & $M$ & $S D$ & $M$ & $S D$ & \\
\cline { 2 - 5 } & & & & \\
PT (Perspective-Taking) & 22,60 & 3,243 & 23,86 & 3,852 & 2,334 \\
FS (Fantasy) & 23,84 & 4,156 & 24,55 & 4,987 & 1,016 \\
EC (Empathic concern) & 24 & 4,343 & 26,47 & 3,826 & 3,575 \\
PD (Personal distress) & 19,31 & 4,342 & 19 & 5,094 & $-0,437$ \\
\hline
\end{tabular}

Notes: $\mathrm{t}_{\mathrm{e}}-$ empirical score of Student's t-test; $\mathrm{t}_{\mathrm{t}}=1,968$ at $\alpha=0.05 ; 2,592$ at $\alpha=0.01 ; \alpha-$ level of statistical significance

$N=302$; 
In particular, we can see that female volunteers are characterized by higher scores on the above-mentioned scales if compared to male volunteers, which is indicative of a more evident tendency to experience a sense of care in situations of rendering aid, as well as the ability to put himself/ herself in the recipient's place.

In our opinion, the results of correlation analysis of parameters of readiness to carry out the VA with the indicators of its meaningfulness are of particular interest. As mentioned above, the sampling of volunteers of the SVM is statistically reliably differs from the normative sample (data of D. Leontyev) on the scales of meaningfulness. Alongside with the scales of readiness, as can be seen from the above-presented data, there is a range of indicative correlations (see Table 3). In particular, a negatively directed correlation between the «PD» scale and the LMO instrument scales draws attention at the high level of statistical significance. The above-mentioned results, as it turned out, are indicative of the interconnection between the level of meaningfulness and the level of readiness to direct negative feelings at himself/ herself in connection with staying in the situation of assistance. This, as a whole, confirms a close interconnection between the established socio-psychological characteristics of the VA that are taken into account.

Table 3. Results of the correlation analysis on scales of LMO \& IRI instruments

\begin{tabular}{cccccc}
\hline & PT & FS & EC & PD & Age \\
\hline PT & 1 &, $187^{* *}$ &, $305^{* *}$ &,$- 174^{* *}$ & \\
FS &, $187^{* *}$ & 1 &, $316^{* *}$ & & \\
EC &, $305^{* *}$ &, $316^{* *}$ & 1 & & \\
PD &,$- 174^{* *}$ & & & 1 & \\
ML &, $198^{* *}$ & &, $266^{* *}$ &,$- 413^{* *}$ & \\
Purpose &, $205^{* *}$ & &, $283^{* *}$ &,$- 324^{* *}$ &, $139^{*}$ \\
Process &, $185^{* *}$ & 0,108 &, $183^{* *}$ &,$- 276^{* *}$ & \\
Result &, $201^{* *}$ & &, $198^{* *}$ &,$- 447^{* *}$ & \\
LC Me &, $153^{* *}$ & &, $252^{* *}$ &,$- 403^{* *}$ & \\
LC Life &, $135^{*}$ & &, $162^{* *}$ &,$- 360^{* *}$ & \\
Gender &,$- 127^{*}$ & &,$- 212^{* *}$ & & \\
Age & & &, $186^{* *}$ &, $194^{* *}$ & \\
\hline
\end{tabular}

Notes: ML - meaningfulness of life; LC Me - locus of control Me; LC Life - locus of control Life.

$N=302 ; *_{-} \alpha=0.05 ; *_{-} \alpha \geq 0.01$; score shown $\varrho \geq 0,1$;

$\varrho-$ Spearman rank correlation coefficient; $\alpha$ - level of statistical significance.

At the same time, as we can see from the above-mentioned results, characteristics of the age distribution have turned to be not significant as for 
indicators of the meaningfulness (there is only one correlation at the significance level $\alpha=0.05$ on the scale «purpose»). At the same time, age characteristics are more closely connected with the IRI indicators. In particular, we can observe positive correlations at a high level of statistical significance on «EC» and «PD» scales, which is indicative of the fact that volunteers of the older age group are more inclined to use these constituents of empathy as the aid resource.

As we understand individual value-motivational trends as motivational factors, it was important for us to ensure the conformity of such an approach to possibilities of its empirical realization. That is why in order to determine indicators of those variables, which represent the specificity of scores at an individual level of analysis, we used the PVQ instrument. In particular, it is known that this instrument is based on the model conformable with the just specified sense of values as motivational trends (Schwartz, 1992).

As we can see, the comparison of data, obtained in our first study, with the findings of the research of the ATO volunteers, carried out in 2015 on the basis of the "Caramelia» LLC by L. Matviyenko and K. Alekseychenko (Matviyenko \& Alekseychenko, 2016, p. 57), shows a range of distinguishing characteristics (see Figure 1). 
Gender and Age Specificity of Determination of Value-motivational Attitudes ... Larysa SPITSYNA \& Hennadiy KOVAL

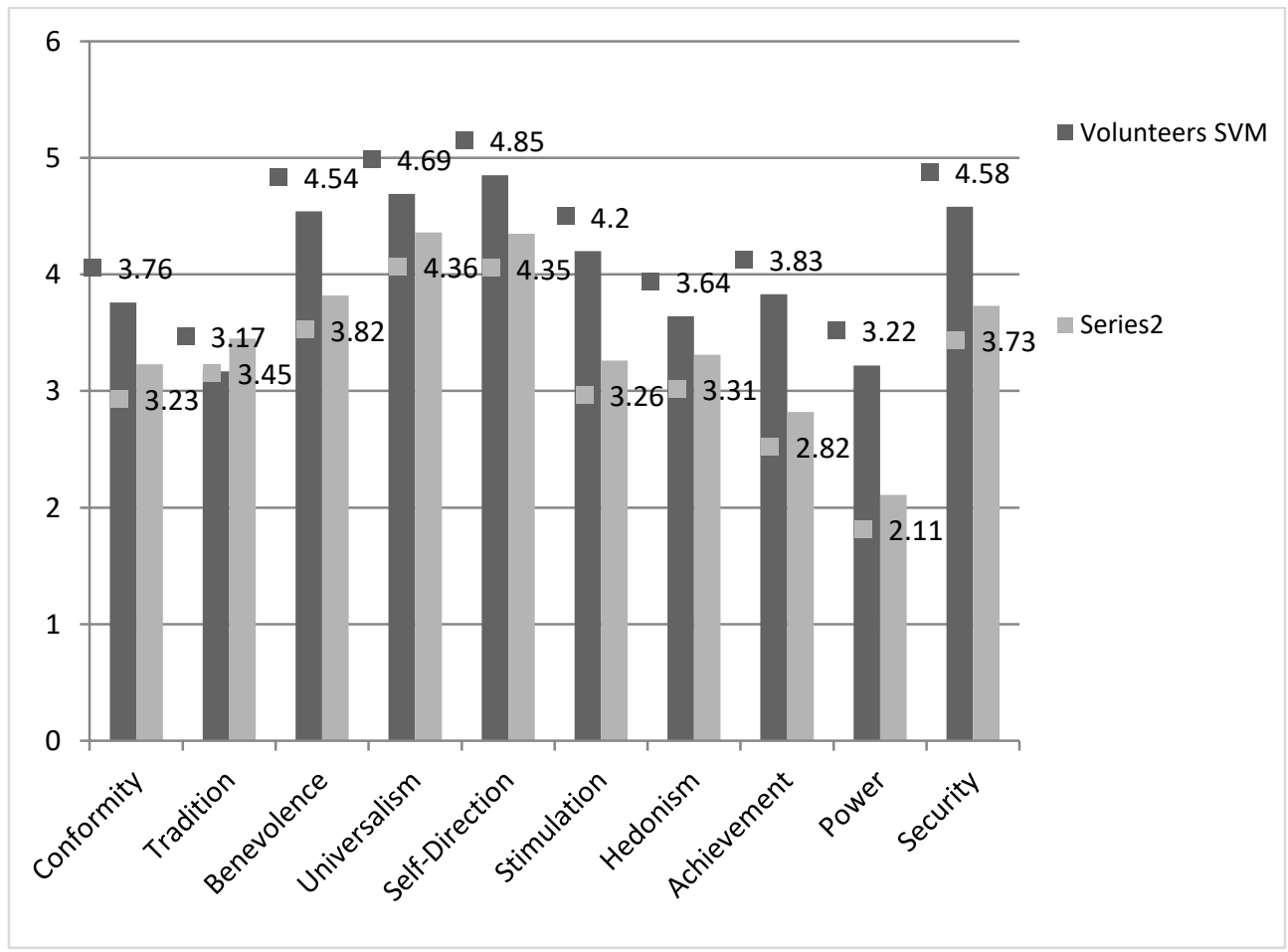

Figure 1. The results of a comparative analysis of samples of volunteers on the scales of the PVQ instrument

In particular, we can observe the following. According to our study findings value-motivational trends of volunteers take higher scores by the specific majority of indicators (a minor exception is only on the scale «Tradition»). At the same time, generally there is a clear trend of domination of separate blocks of values with slight differences within those very blocks. In particular, the average indicators of the value «Conformity» of the SVM volunteers dominate the indicators on the scale «Tradition» within the block «Conservation». Conformable correlation can be seen on the scales «Stimulation» and «Hedonism», where scores on the first one are prevailing for the SVM volunteers. In our opinion, another characteristic feature is higher scores of the SVM volunteers on the scales «Power» and «Achievement», which can be related to the fulfilment of functions of the VA management by individual volunteers. As well as, on the scale «Security», which, taking into consideration the involvement in fulfilment of the tasks in the area of national security and defence, is hardly disputable for interpretation. However, there is a reasoned remark concerning all the above 
mentioned, i.e: - the presence of high scores on all the scales in the sample of SVM volunteers needs an explanation, as such results hamper an unambiguous interpretation of the data obtained.

To some extent, such a nature of data can be explained from the analysis of results of distribution of functional relations (see Table 4).

Table 4. Results of the correlation analysis on scales of LMO, IRI \& PVQ instruments

\begin{tabular}{|c|c|c|c|c|c|c|c|c|}
\hline & $\begin{array}{l}\text { Con- } \\
\text { formity }\end{array}$ & $\begin{array}{l}\text { Tradi- } \\
\text { tion }\end{array}$ & $\begin{array}{l}\text { Benevo- } \\
\text { lence }\end{array}$ & $\begin{array}{c}\text { Jniversal } \\
\text { ism }\end{array}$ & $\begin{array}{l}\text { Self- } \\
\text { direc- } \\
\text { tion timula- } \\
\text { tion }\end{array}$ & $\begin{array}{l}\text { - Fedon- } \\
\text { ism }\end{array}$ & $\begin{array}{l}\text { Achieve- } \\
\text { ment }\end{array}$ & $\begin{array}{l}\text { - 'ow-Secu- } \\
\text { er rity }\end{array}$ \\
\hline Age & ,239** & $248^{* *}$ &, $137^{*}$ & ,145* & ,156** &, $277 * *$ &,$- 313^{* *}$ & $\begin{array}{c}- \\
319 * \\
*\end{array} *{ }^{300 *}$ \\
\hline Gender & & &,$- 126^{*}$ &,$- 157^{* *}$ & $203^{-}$ & ,112 & & $\begin{array}{l}- \\
158^{*} \\
*\end{array}$ \\
\hline ML & & & ,193** & ,120* & $119 * *, 339 * *$ & & ,152** & $30 * 115^{*}$ \\
\hline Purpose & ,115* & & ,278** & & $389 * *, 224 * *$ & & ,136* & $\begin{array}{c}181 * \\
*\end{array}$ \\
\hline Process & ,123* & &, $181^{* *}$ & ,165** & $371^{* *}, 285^{* *}$ & ,138* &, $176^{* *}$ & $127 * \begin{array}{c}179 * \\
*\end{array}$ \\
\hline Result & & &, $152 * *$ & & $336 * *, 299 * *$ & & 0,101 & \\
\hline $\mathrm{LC} \mathrm{Me}$ & & & ,204** & 0,104 & $114^{* *}, 278^{* *}$ & & ,146* & $\stackrel{62 *}{*} 140 *$ \\
\hline LC Life & & & & & $280 * *, 249 * *$ & &, $117^{*}$ & $\begin{array}{c}\text { ),10 } \\
4 \\
-\end{array}$ \\
\hline PT & ,143* & &, $298^{* *}$ &, $237 * *$ & $157 * *$ & & & $\begin{array}{l}165^{*} \\
*\end{array}$ \\
\hline FS & & &, $203 * *$ & ,188** & $231^{* *}, 183^{* *}$ &, $116^{*}$ &, $211^{* *}$ & $139 *$ \\
\hline EC & ,396** & $279 * *$ &, $526^{* *}$ &, $471 * *$ & $318^{* *}$ & & & $\begin{array}{c}306^{*} \\
*\end{array}$ \\
\hline PD & ,280** & $261^{* *}$ & & & $315^{* *} \cdot 387^{* *}$ &,$- 147 *$ &,$- 153 *$ & $\begin{array}{cc}- & 249 * \\
285^{*} & * \\
* & \end{array}$ \\
\hline
\end{tabular}

Notes: ML - meaningfulness of life; LC Me - locus of control Me; LC Life - locus of control Life.

$N=302 ; *_{-} \alpha=0.05 ; *_{-} \alpha \geq 0.01$; score shown $\varrho \geq 0,1$;

$\varrho-$ Spearman rank correlation coefficient; $\alpha$ - level of statistical significance. 
Let us consider in detail the data of calculation of the Spearman rank correlation in relation to the LMO, IRI and PVQ scales. In particular we can see a high representation of correlations of value indicators with the indicators of the IRI scales. At the same time these correlations are mainly of a positive nature as a whole and reproduce the dynamics of the level of value representation in the sample as a whole. For instance, indicators on the scale «EC» reproduce the dynamics of correlations of the value «Security», and the scales themselves demonstrate a high reliable positive correlation $(\varrho=, 306 ; \alpha=0.001)$. At the same time it is impossible to note a non-uniform nature of correlation of value indicators and the scale «PD». Particularly, we can see a positive nature of correlations with the values of the block «Conservation», but a negative one with all the other value scales. Such data are indicative of a non-uniformity of motivational trends, realized by the SVM volunteers, when providing aid. Moreover, the presence of the abovementioned negative correlation can also be observed through the presence of a negative correlation between the scales «PT» and «Power» ( $\varrho=-, 165 ; \alpha$ $=0.01$ ). The last functional load, showing the opposition of directedness between the ability to put himself/herself in the recipient's place on the one hand, and the motivational tendency to fulfil functions of a leader on the other hand, seems quite logical.

Hence, the presented data convince us in the following. Depending on what motivational trends dominate in an individual profile of the SVM volunteer, and, therefore, direct his/her individual activity, the resource of readiness that is implemented in rendering aid, is specifically related to them.

The results of calculation of the rank correlation between the indicators of value scales and LMO scales are also indicative of representative results. In particular, the results convince us that the meaningfulness of activity, and in case of our study - meaningfulness of the activity on providing aid, can draw its high indicators from realization of various motivational trends. For instance, we can see that there is a high functional load between the scales «ML» and «Benevolence» $(\varrho=, 193$; $\alpha=0.01)$, «Self-direction» ( $\varrho=, 419 ; \alpha=0.001)$, «Stimulation» $(\varrho=, 339$; $\alpha=0.001)$. What is noteworthy is the presence of a certain specificity of distribution of correlations between individual LMO scales and values. In particular, data on the scales «LC Me» and «LC Life» demonstrate that a significant constituent part of the meaningfulness of activity of the SVM volunteer is a high ability to self-control. Hence, as a conclusion - a higher significance of the intergroup connection between the representatives of the SVM for the inner world of the volunteer's personality and a lower one - for the life-world. 
Hence, we can summarize that there is the specificity of interconnection between a certain motivational tendency, resources of readiness to provide aid and the sources of meaningfulness. This makes it possible to reveal the specificity of conditioning of the value range of generalization of established characteristics of the VA by socio-psychological factors.

In its turn, if we pay attention to the present correlations between the PVQ scales and scores of the characteristics of gender and age distribution of data (see Table $4 \& 5$ ), we can notice a negative correlation between the scales that are constituents of the blocks «Openness to change» and «Self-enhancement» (scales of Stimulation/ Hedonism / Achievement/ Power) and the age of respondents. I.e., we can understand that the younger the respondents are the more common high scores on the above-mentioned value-motivational trends are for them.

Table 5. Comparison of the results of the calculation of the Spearman rank correlation coefficient and the Pearson connectivity coefficient on the gender distribution

\begin{tabular}{|c|c|c|c|c|c|c|c|c|c|c|}
\hline & Age & ML & Purpose & Process & Result & LC Me & LC Life & PT & EC & PD \\
\hline$\varrho$ &,$- 186 * *$ &,$- 182^{* *}$ &,$- 161 * *$ &,$- 152^{* *}$ & $-0,083$ &,$- 172^{* *}$ &,$- 142^{*}$ &,$- 127 *$ & $-0,06,212^{* *}$ & $\begin{array}{c}0,03 \\
1\end{array}$ \\
\hline$P$ & 0,208 & 0,250 & 0,156 & 0,230 & 0,134 & 0,211 & 0,186 & 0,124 & $0,1380,195$ & 0,06 \\
\hline$\alpha$ & 0,008 & 0 & 0,023 & 0 & 0,064 & 0,001 & 0,004 & 0,093 & $0,05 \quad 0,003$ & 0,58 \\
\hline & $\begin{array}{l}\text { Con- } \\
\text { formity }\end{array}$ & $\begin{array}{l}\text { Tradi- } \\
\text { tion }\end{array}$ & $\begin{array}{l}\text { Benevo- } \\
\text { lence }\end{array}$ & $\begin{array}{l}\text { Univer- } \\
\text { salism }\end{array}$ & $\begin{array}{l}\text { Self- } \\
\text { Direc- } \\
\text { tion }\end{array}$ & $\begin{array}{l}\text { Stimu- } \\
\text { lation }\end{array}$ & $\begin{array}{c}\text { He- } \\
\text { donism }\end{array}$ & $\begin{array}{c}\text { Achieve } \\
\text { ment }\end{array}$ & $\begin{array}{cc}\text { Pow Secu- } & \text { er rity }\end{array}$ & \\
\hline$\varrho$ & 0,012 & 0,061 &,$- 126^{*}$ &,$- 155^{* *}$ &,$- 203 * *$ & $-0,08$ & 0,111 & $-0,009$ & $0,067,159 * *$ & \\
\hline$P$ & 0,042 & 0,079 & 0,123 & 0,130 & 0,185 & 0,07 & $0,221 *$ & 0,033 & $0,076 \quad 0,187$ & \\
\hline$\alpha$ & 0,912 & 0,391 & 0,0990 & 0,074 & 0,005 & 0,474 & 0,000 & 0,847 & $0,4110,004$ & \\
\hline
\end{tabular}

Notes: ML - meaningfulness of life; LC Me - locus of control Me; LC Life - locus of control Life.

$\varrho$ - Spearman rank correlation coefficient; $P$ - Pearson connectivity coefficient; $\alpha$ - level of statistical significance;

The respondent gender parameter can partially explain the nature of the data obtained in our study. However, let us note that as the data on the parameter have the signs of a nominal scale of measurement, in order to analyse them we have additionally calculated the Pearson correlation coefficient. Furthermore, their comparison with the results of calculation of the Spearman rank correlation coefficient convinces of their practical 
identity (see Table 5). That is why we rely on the results of the correlation analysis in our further analysis and interpretation.

In this area of the analysis let us draw your attention to the fact that the scales, which have the highest scores in the sample of the SVM volunteers, are correlation-loaded, i.e. the scales «Universalism» $(\varrho=-, 157)$, «Self-Direction» ( $\varrho=-, 203)$, «Security» $(\varrho=-, 158)$. There is a negative correlation at the significance level $\alpha=0.01$ on the above-mentioned scales. The scale «Benevolence» $(\varrho=-, 126)$ negatively correlates with gender at the level $\alpha=0.05$. It means, that we can observe higher scores typical for female volunteers.

Such findings, as a whole, prove the previously identified peculiarities of interconnection between the gender of respondents and empathic resource of readiness, implemented in providing aid. In particular, in view of the fact that the values «Benevolence», «Universalism» and, to a lesser extent, «Self-Direction» find the ways of their generalization within the block «Self-transcendence» (Schwartz, 1992; Semkiv, 2010), and the interconnection between the gender of the respondent with the IRI «EC» and «PT» scales gains a statistical significance (see Table $2 \& 3$ ), it is possible to make the following conclusion. Affective and cognitive constituent of the ability to put himself/herself in the place of other person also finds the way of its explication in the dimension of the values discourse, and in case of providing aid to the participants in military conflict, additionally specifies the peculiarities of socio-psychological conditioning of the aid also with the volunteer's gender.

\section{Discussion}

From the presented findings of the study we can make a conclusion in the form of several statements concerning the role of gender and age of the volunteer in the system of socio-psychological factors of the VA.

First of all, let us note that the identified correlation between the indicators of meaningfulness and gender distribution, where there is their significant shift from average towards a higher number for female volunteers, is a significant peculiarity of the SVM volunteers. In particular, data by D. Leontyev provide evidence of an opposite tendency - indicators of meaningfulness prevail in the normative sample on all the scales of the test for men (Leontyev, 2000). Moreover, it is noteworthy that the presented specificity of the interconnection between value-motivational trends and sources of meaning also reproduces the presence of a certain non-uniformity in the influence on the variability (shift of scores) of this or that valuemotivational trends in connection with various sources of meaningfulness. 
However, a more detailed analysis of this tendency requires a separate study and presentation.

We can also note one more significant peculiarity typical for the SVM volunteers. Namely: the data, obtained as a result of the correlation analysis, is indicative of a range of correlations between the IRI scales. In particular, it is known from the findings of the previous studies, that there was a correlation of indicators between the scales $\langle\mathrm{FS}\rangle$ and $\langle\mathrm{EC}\rangle$ and a negative correlation of indicators on the scales «PT» and «PD» in other samples (Karjagina et al., 2013, p. 50). In addition, our data also reveal the correlation between the scales «PT» and «EC». Considering the fact that there is also a shift from the average towards higher scores on these scales for female volunteers, we can quite reasonably connect the presence of the correlation specified in our sample with the gender specificity. I.e., we can say the following - there is a gender-based dependence of the interconnection between the affective constituent of empathy, which is manifested in experiencing the sense of warmth and amiability in the situation of providing aid and the cognitive constituent, which is manifested in the ability to put himself/herself in the place of other person (recipient).

On the other hand, depending on the gender-specific differences, however, connected with the age of respondents, there is the result, obtained in our study, which is indicative of the implementation of the sense of awkwardness and intenseness a resource in a situation of providing aid (scale of «PD»). At the same time such a peculiarity typical for volunteers of the older age group, is connected not only with age, but also with the specificity of value-motivational trends. In particular, an important condition is the orientation on the values of the block «Conservation» - «Security», «Conformity» \& «Tradition». It is important to mention that the findings of the previous study did not show such a specificity of interconnection. Moreover, indicators on the scale were interpreted as a negative prognostic variable in relation to the prosocial behaviour of the personality (Juujärvi et al., 2012; Myyrya et al., 2010). We may make an assumption that this very tendency is the basis of the phenomenon that is manifested in volunteers and psychosocial support specialists proportionally to the duration of their professional activity, which is called «compassion fatigue», early identification of which is a key to timely preventive activities on prevention of the personality burnout.

In the context of the revealed gender-related interconnection, which in some way reflects the phenomenology of empathy in the valuemotivational coordinates, and connects it, first of all, with the values of the block «Self-transcendence», it is interesting to mention the following. In 
general such data confirm the findings of the research by Balliet et al., where it is shown that the highest positive functional connection is between an integral index of empathy and the value «Benevolence» (Balliet et al., 2008). However, the analysis of the interconnection is not an integral index of empathy, but with its separate constituent parts, put in the IRI instrument (Davis, 1983) lets us note not only its gender, but also its age specificity. In particular, a set of established positive functional interconnections between the three indices of empathy (scales of «PT», «EC» \& «FS») and values of the block «Self-transcendence» (scales of «Benevolence», «Universalism» \& «SelfDirection») are fully conformable to the Balliet hypothesis. However, the nature of interconnections of the scale FS makes it possible to note its interconnection not only with the block «Self-transcendence», but also with constituents of the block «Self-enhancement» (values - «Stimulation», «Hedonism», «Achievement»). In view of the fact that negative dependencies between age of respondents and the block «Self-enhancement» are reproduced for the scale «FS», and it has the highest density with the values «Self-Direction» and «Achievements», it is reasonably to summarize that this empathic resource is not gender-specific, and is specific in relation to age and is typical for volunteers of a younger age group.

The established negative nature of correlation between the value «Power», which is reproduced on the scale «PT», but is not present on the scale $« \mathrm{EC} »$, in its turn also lets us disproved the gender-related specificity. In view of the fact that we connect high indicators on this scale with the realization of functions of leadership and management, when carrying out the VA, we can reasonably assume that the motivation potential of this value is highly-sought for especially in the volunteers of the middle age group.

As for the interconnections of age with value-motivational trends, let us note that an interesting peculiarity is the reproduction of distribution of continuum of values on this parameter almost in half. At the same time the end poles of the continuum demonstrate the highest scores of density of such an interconnection, which gradually declines to the centre, where the role of the latter is performed by the indicators of the value «Self-Direction».

Such characteristics of correlation loads respectively indicate that for young volunteers' main value-motivational trends are concentrated within the factor that coincides with the block of values «Self-enhancement». Therefore, the carrying out of the VA by this subgroup of volunteers is connected with the realization of the will for interpersonal interaction and an active life, as well as for identity formation and finding a place in the community. This creates preconditions for the fact that the feeling of 
success of activity is connected with the orientation on the internal reward, the feeling of authenticity, freedom and self-realization.

Orientations on the process of activity, a desire to derive pleasure are more typical for volunteers of the middle age group; spontaneity and distinctiveness are appreciated. A will for a social influence is also typical, but to a lesser extent, which is proved by their orientation on realization of the motivation potential of the value «Power», which creates preconditions for a desire to fulfil functions of a leader, orientation of taking responsibility.

Instead, orientation on the value potential of motivation trends is more typical for volunteers of older age group, which could be generalized in a terminological construction «life saving and protection». Hence, the carrying out of the VA by this subgroup of volunteers is connected with the realization of the desire to take care, oriented on maintaining main values of humanness. Therefore, the feeling of a success of activity is connected with orientation on the internal reward as well (data on the scale locus of control Me of the LMO instrument), which consists in the feelings of self-realization through experiencing a sense of concern, his/her importance and involvement in realization of important tasks in the area of national security and defense.

\section{Study limitation}

The presented results as for the outer validity are limited by such a segment of volunteering as the social movement on providing aid to victims and participants in the military conflict. It makes it impossible to directly extrapolate them to the specificity of the VA within the boundaries of other segments of volunteer aid - for example, in the area of environmental protection, protection of the rights of animals, medical volunteering, volunteering in political and sporting social processes, etc. Hence, it is necessary to further find out if the revealed specificity of the role of gender and age characterizes only the SVM volunteers, or, instead, such a nature of conditioning is typical for other segments of the VA as well and more widely - prosocial activity as a whole.

\section{Conclusions}

The nature of the data, obtained in our study, depends on a number of circumstances. Namely: individual values of respondents condition the specificity of interconnection between the value-motivational trend, empathic resource of readiness to provide aid and sources of meaningfulness, thus letting identify a certain motivational complex, the 
motivational potential of which is realized by a volunteer at the level of an individual VA. Individual values, in its turn, reveal the tendency to be sensitive to peculiarities of age and gender distribution. Hence, when answering to the question concerning the specificity of commonality as a characteristic of the intergroup connection between the SVM volunteers, we should come to the following conclusion. Significant factors of the specificity of commonality of the SVM are parameters of gender and age. Therefore, gender and age characteristics of volunteers are a significant constituent in the system of factors of the socio-psychological conditioning of the VA.

Thus, the belonging to this or that gender and age group, specified by volunteers, is quite an informative token, which lets us consider the characteristics of the age and gender of volunteers not only as a significant constituent in the system of factors of socio-psychological conditioning of the VA, but also as a significant prognostic variable, which makes it possible to connect them with peculiarities of value-motivational trend, the motivational potential of which is realized directly in providing aid.

At the same time the prospect of a further study is in finding answers to the following questions. Does the identified specificity of gender and age characteristics in the system of factors of socio-psychological conditioning of the VA characterize only SVM volunteers? Or, can the results be extrapolated to other segments of volunteering and prosocial activity as a whole? The answer to this question is interesting given the opportunities to generalize the revealed specificity of interconnections in the system of socio-psychological factors of the VA as the basis for singling out the criteria for socio-psychological classification of the volunteer communities.

\section{References}

Balliet, D., Joireman, J., Daniels, D., \& George-Falvy, J. (2008). Empathy and the Schwartz Value System: A Test of an Integrated Hypothesis. Individual Differences Research, 6(4), 269-279.

Berger, P., \& Luckmann, T. (1966). The social construction of reality. A Treatise in the Sociology of Knowledge. Penguin Books

Clifford, G. (1983). Local knowledge: further essays in interpretive anthropology. Basic Books.

Davis, M.H. (1983). Measuring individual differences in empathy: Evidence for a multidimensional approach. Journal of Personality and Social Psychology, 44(1), 113-126. https://doi.org/10.1037/0022-3514.44.1.113 
Gergen, K.J. (1985). The social constructionist movement in modern psychology. American Psychologist, 40(3), 266-275. https://doi.org/10.1037/0003$\underline{066 X .40 .3 .266}$

Guseltseva, M. (2018). Svidomist yak broblema psykholohiyi: postneklasychnye interpretatsiya [Consciousness as a problem of psychology: postnonclassical interpretation]. Psychology \& society, 3-4, 51 66.https://doi.org/10.35774/pis2018.03.051

Haken, H. (2009). Synergetics: Basic Concepts. In A. Hutt \& H. Haken (Edsl.), Synergetics. Encyclopedia of Complexity and Systems Science Series (pp. 5-30). Springer. https://doi.org/10.1007/978-1-0716-0421-2 533

Juujärvi, S., Myyry, L., \& Pesso, K. (2012). Empathy and values as predictors of care development. Scandinavian Journal of Psychology, 53(5), 413-420. https://doi.org/10.1111/j.1467-9450.2012.00961.x

Karjagina, T., Budagovskaja, N., \& Dubrovskaja, S. (2013) Adaptacija mnogofaktornogo oprosnika jempatii M. Djevisa [Adaptation of the multivariate questionnaire of empathy M. Davis]. Konsultativnaja psihologija i psihoterapija, 1, 202-227. https://psyjournals.ru/mpj/2013/n1/65006.shtml

Karjagina, T., \& Kuhtova, N. (2016) Test jempatii M. Djevisa: soderzhatelnaja validnost $\mathrm{i}$ adaptacija $\mathrm{v}$ mezhkulturnom kontekste [Empathy Test by M. Davis: Content Validity and Adaptation in an Intercultural Context]. Konsultativnaja psibologija i psihoterapija, 4, 33-61. https://psyjournals.ru/mpj/2016/n4/karyagina kukhtova.shtml

Korniyevskyy, O., \& Horyelov, D. (2015) Ukrayinskyy volonterskyy rukh u konteksti svitovoho dosvidu [Ukrainian volunteer movement in the context of world experience]. Naukovo-analitychnyy shchokvartalnyy zbirnyk NISD "Stratehichni priorytety», 1(34). 95-100. http://old2.niss.gov.ua/content/articles/files/volonter-697e4.pdf

Koval, H., \& Spitsyna, L. (2021). Empathy as a resource of socio-psychological support in the system of factors of volunteering. Insight: the psychological dimensions of society, 5, 30-45. https://doi.org/10.32999/2663-970X/2021-5-3

Koval, H. (2019) Empirychna model doslidzhennya spilnosti yak sotsialnopsykholohichnoho chynnyka volonterskoyi diyalnosti [Empirical model of community research as a socio-psychological factor of volunteering]. «Sotsiokulturni ta psykholohichni vymiry stanovlennya osobystosti» Mat. II Mizhnarodnoyi nauk.-prak.t. konf. [«Socio-cultural and psychological dimensions of personality development» Mate. II International scientificpractical. conf.]. (pp. 127-130). FOP Vyshemyrskyy V. S. http://ekhsuir.kspu.edu/handle/123456789/9233

Lee, M. (2019). Volunteering and Happiness: examining the differential effects of volunteering types according to household income. Journal of Happiness Studies, 20, 795-814. https://doi.org/10.1007/s10902-018-9968-0 
Gender and Age Specificity of Determination of Value-motivational Attitudes ... Larysa SPITSYNA \& Hennadiy KOVAL

Leontyev, A. (1975). Deyatelnost, soznaniye, lichnost [Activity, consciousness, personality]. Politizdat.

Leontyev, D. (2000). Test smyslozhiznennykh oriyentatsiy [Test of life-meaning orientations]. Smysl.

Liotard, Z. F. (1998). Sostoyaniye postmoderna [Postmodern state]. Spb: Aleteyya

Lyuta, L. (2016). Instytutsializatsiya volonterskoho rukhu v merezhevomu suspilstvi [Institutionalization of the volunteer movement in a network society]. Aktualni problemy psykholohiyi. Tom VII. Ekolobichna psykholobiya, 41, 220228.http://www.appsychology.org.ua/data/jrn/v7/i41/24.pdf

Matviyenko, L., \& Alekseychenko, K. (2016) Osobystist volontera u psykholohichnomu vymiri [The personality of a volunteer in the psychological dimension]. Rynok pratsi ta zaynyatist naselennya, 1, 55-59.

http://nbuv.gov.ua/UJRN/rpzn_2016_1_14

Myyrya, L., Juujärvi, S., \& Pesso, K. (2010). Empathy, perspective taking and personal values as predictors of moral schemas. Journal of Moral Education, 39(2), 213-233. https://doi.org/10.1080/03057241003754955

Oswald, P. (1996). The effects of cognitive and affective perspective taking on empathic concern and altruistic helping. The Journal of social psychology, 136(5), 613-623. https://doi.org/10.1080/00224545.1996.9714045

Polanyi, M. (1958). Personal knowledge: Towards a post-critical philosophy. Routledge \& Kegan Paul.

Schwartz, S. (1992). Universals in the content and structure of values: Theoretical advances and empirical tests in 20 countries. Advances in experimental social psychology, 25(1), 1-65. http://dx.doi.org/10.1016/S0065-2601(08)60281-6

Semkiv, I. (2010). Indyvidualni tsinnosti yak psykholohichni mekhanizmy formuvannia sotsialnoho kapitalu [Individual values as psychological mechanisms of social capital formation]. Problemy suchasnoi psykholohii, 10, 699-709. http://journals.uran.ua/index.php/2227-6246/article/view/161783

Simsa, R., Rameder, P., Aghamanoukjan, A., \& Totter, M. (2019). Spontaneous volunteering in social crises: Self-organization and coordination. Nonprofit and Voluntary Sector Quarterly, 48(2), 103-122. https://doi.org/10.1177/0899764018785472

Slyusarevskyy, M. (2013). Istoriohrafichni ta metodolohichni koordynaty teoriy sotsialnoyi psykholohiyi: monohrafiya [Historiographical and methodological coordinates of theories of social psychology: monograph]. Imeks-LTD.

Spitsyna, L. (2011). Vchynok i narratyvnyy pidkhid v doslidzhenni orhanizatsiynoyi kultury [An act and a narrative approach in the study of organizational culture]. Actual problems of sociology, psychology, pedagogy, 13, 173-178. http://apspp.soc.univ.kiev.ua/index.php/home/article/view/700 
Tytarenko, T. (2014). Sotsialno-psykholohichni praktyky osobystisnoho zhyttiekonstruiuvannia [Socio-psychological practices of personal life design]. In T. Tytarenko, O. Kochubeinyk, \& K. Cheremnykh (Eds.), Psykholobichni praktyky konstruiwvannia zhyttia v umovakh postmodernoi sotsialnosti [Psychological practices of constructing life in postmodern society.]. Milenium.

Wymer Jr, W.W. (1997). Segmenting volunteers using values, self-esteem, empathy, and facilitation as determinant variables. Journal of Nonprofit \& Public Sector Marketing, 5(2), 3-28. http://dx.doi.org/10.1300/J054v05n02 02

Yurchynska, H., \& Krutsyuk, O. (2017). Volonterska diyalnist: sut i psykholohichni determinant [Volunteer activity: essence and psychological determinants]. Ukrayinskyy psykholobicbnyy z.burnal, 2(4), 188-204. http://upj.com.ua/indexa.php?page $=$ abch

Yurchynska, H., \& Krutsyuk, O. (2018) Vzayemozvyazok zhyttyestiykosti osobystosti volontera ta yoho motyvatsiyi [The relationship between the vitality of the volunteer's personality and his motivation]. Ukrayinskyy psykholohichnyy zhurnal, 2, 163-179. http://upi.com.ua/indexa.php?page=ab two_eight_13 